\title{
Chris Allen: Housing market renewal and social class 2008, London: Routledge, ISBN9780415415613
}

\author{
Richard Ronald
}

Received: 25 May 2009/Accepted: 6 November 2009/Published online: 21 November 2009

(C) The Author(s) 2009. This article is published with open access at Springerlink.com

There was a time when class was at the heart of housing debates and working class communities featured heavily in social science research. The dwindling of attention upon working class experiences and the reconstitution of housing issues as market-economic ones is the central concern of Allen's book. Housing Market Renewal (HMR) has been a policy developed in the UK under New Labour aimed at 'improving' neighbourhoods where housing markets have 'failed'. Concentrated poor quality housing has been understood to create sink neighbourhoods that exclude lower income households from the advantages of markets and benefits of investment in owner-occupied housing. Allen takes this as his point of departure, arguing that working class households in the northern towns and cities where HMR has been 'imposed' have derived little benefit from such programmes with many being dispossessed of their homes. He argues that, ontologically, working class households relate to their homes in terms of a 'we being', as sites where their lives with others are played out, which is contrasted to the 'me being' demonstrated among middle class homeowners who seek to use their homes as a means to secure their class position, increase their wealth and impose themselves on the urban landscape. Working class people have been neither disposed to, nor powerful enough to use housing markets and HMR to their advantage. Meanwhile, HMR projects have been an opportunity for local governments and private developers to profit from improvements to well located real estate occupied by poor and run down neighbourhoods.

Allen divides the book into three sections made up of nine chapters in all. Based on a broad insight from the British social class literature, the first and shortest section of the book develops a theoretical critique of social class in sociology. The second section introduces the housing element. The concern is that while economic Marxists have misinterpreted the significance of social class, sociological research and debate has neglected working class experiences and become preoccupied with consumption and postmodern debates related to urban gentrification that reflect the middle class presumptions of contemporary academics. Allen's critique is, on the whole, insightful and informed and

R. Ronald $(\bowtie)$

OTB Research Institute for Housing, Urban and Mobility Studies,

Delft University of Technology, Delft, The Netherlands

e-mail: r.ronald@tudelft.nl 
develops an existential understanding that establishes different modes of class-being in the market for houses. There is simply not room to do it justice here, but an argument is established (drawing upon both the academic literature and primary interview data) concerning how working class people have come to accept the middle class logic of housing that dictates the use of homes as locales of consumption and investment mechanisms. It is a way of relating to and benefiting from housing that, nonetheless, most working class households are excluded from. There is some notable tub thumping is these early chapters, although Allen does have a point concerning the revival of class issues and in deriding the preponderance of sociological thinking concerned with identity and consumption.

These first two sections make up the first half of the book, the last chapter of which brings in the issue of HMR and how alien it is to working class households who dwell in neighbourhoods that have been targets of this policy. The second half of the book, which is the third section, focuses on the empirical case of Liverpool and the inner city neighbourhood of Kensington. Based on a broad array of empirical interviews and secondary data as well an intimate familiarity with Kensington, Allen examines the impact of HRM in context of national policy issues as well as local agendas related to urban regeneration leading up to Liverpool's year as 'City of Culture'. Critical arguments are developed related to the experiences of working class households and the need (or absence of it) felt for housing market renewal. There is also considerable critique of the 'end of history' discourses that surround working class neighbourhoods and old terraced housing. Essentially, the language of 'neighbourhood decline', he argues, has served the interests of those who benefit from the construction of new modern housing and middleclass households better placed to take advantage of regeneration.

Allen's appraisal is, if nothing else, provocative. Few books in the housing field these days capture a sense of passion concerning government policies and the inequalities they create. This may well be to do with how most housing research in the UK is now funded under the constraints of evidenced based policy. Allen manages to be outraged, but with considerable sensitivity to theoretical issues and with a thorough evidence base drawn from a diversity of sources from government reports to in-depth interviews with local residents, government officials and market intermediaries. I have the feeling however, that many readers will not take so kindly to Allen's tone or his mounted hobby horse approach to the working classes and the evils of HMR. Indeed, this is by no means a comprehensive or balanced consideration of recent housing market initiatives and there is little room in Allen's thinking for the possibility that many neighbourhoods and working class people benefit. Moreover, there is often a rather caricatured view of social actors. On one side are poor 'ordinary working people' who appear somewhat of a socially, culturally and ethnically homogenous class reminiscent of a 'salt of the earth' flat cap doffing working class of the past. On the other side are self interested middle class agents. While I was largely convinced by Allen's championing of the working class as a neglected category, there is an idealisation of Liverpool's poorer neighbourhoods and people and condemnation of the English public officials and middle classes, who are a rather soft target. Aren't estate agents, developers, policy makers and middle class academics ordinary working people too?

Paul Watt is quoted on the back cover of this book to say, 'Chris Allen's book represents a major contribution both to class analysis and housing studies'. I wouldn't disagree. Although not impartial, there is certainly a need for Allen's voice in the housing policy debate. Moreover, while the book sometimes labours its points, the writing style is engaging and accessible. The earlier chapters in particular offer a useful resource for teachers and students of social class, housing and gentrification. I also expect that the latter 
chapters will be of value to those seeking to build a critique of housing policy and the market fixated reasoning of New Labour.

Open Access This article is distributed under the terms of the Creative Commons Attribution Noncommercial License which permits any noncommercial use, distribution, and reproduction in any medium, provided the original author(s) and source are credited. 